\title{
Sexual Myth Beliefs and Associated Factors in University Students
}

\section{Üniversite Öğrencilerinde Cinsel Mit İnançları ile İlişkili Faktörler}

\author{
Servet Aker ${ }^{* 1}$, Mustafa Kürşat Şahin², Gülay Oğuz ${ }^{3}$
}

\begin{abstract}
Background: Sexual myths are exaggerated, incorrect and unscientific ideas on sexuality that people believe to be true. The purpose of this study was to examine factors that may be related to belief in sexual myth in university students. Methods: This study was performed in May 2016 among students from a university in Samsun, Turkey. Five hundred ninety-nine students consenting to participate were included. A questionnaire containing the Sexual Myths Scale (SMS), Eysenck Personality QuestionnaireRevised/Abbreviated Form, Rosenberg Self Esteem Scale and The Sexual Self-Schema Scale (SSS), together with a sociodemographic data form consisting of 15 questions drawn up by the authors, were used in this cross-sectional study. Results: SMS scores were significantly lower in females than in males. SMS scores were negatively correlated with maternal and paternal educational levels and positively correlated with religious belief. Students' scores on the SMS increased as their political beliefs tended to the right and as their religious faith increased. Statistically significant correlation was also determined between students' scores on the SSS and SMS.Conclusion: The most effective mean to preclude sexual prejudices is sexual education begins at an early age and continues throughout psychosexual development. The reasons for dysfunctional sexual beliefs must be revealed for planning a proper sexual education. These factors can be determined with multifaceted, wide-ranging research.
\end{abstract}

Keywords: sexuality, sexual myths, Eysenck personality questionnaire revised-abbreviated form, the sexual self-schema scale

\section{ÖZET}

Giriş: Cinsel mitler, kişilerin cinsel konularda doğru olduğunu düşündükleri ancak çoğu zaman abartılı, yanlış ve bilimsel değeri bulunmayan inançlardır. Bu çalışmanın amacı, üniversite öğrencilerinde cinsel mit inançları ile ilişkili faktörlerin değerlendirilmesidir. Yöntem: Bu çalışma, 2016/Mayıs ayında Samsun'da üniversite öğrencilerinde yapılmıştır. Araștırmaya, çalışmaya katılmayı kabul eden 599 üniversite öğrencisi dâhil edilmiştir. Kesitsel tipteki bu çalışmada, araştırmacılar tarafından hazırlanan 15 sorudan oluşan sosyodemografik veri formu ile birlikte Cinsel Mitler Ölçeği, Eysenck Kişilik Anketi-Gözden Geçirilmiş Kısaltılmış Formu, Rosenberg Benlik Saygısı Ölçeği ve Cinsel Benlik Şeması Ölçeği'nin yer aldığı bir anket formu kullanılmıştır. Bulgular: Kadınlarda erkeklere göre cinsel mitler ölçeği puanlarının istatistiksel olarak anlamlı düzeyde düşük olduğu saptanmıştır. Öğrencilerin cinsel mitler ölçeği puanları ile anne ve babasının eğitim düzeyi arasında olumsuz yönde, dindarlık düzeyi ile olumlu yönde istatistiksel olarak anlamlı bir korelasyon saptanmıştır. Öğrenciler, siyasi olarak sağ düşünceye yaklaştıkça ve psikotik kişilik özellikleri arttıkça cinsel mitler ölçeğinden aldıkları puanların arttı̆̆ı saptanmıştır. Cinsel Benlik-Şeması Ölçeği puanları ile cinsel mitler ölçeği puanları arasında istatistiksel olarak anlamlı bir korelasyon olduğu saptanmıştır. Sonuç: Kişinin cinsel önyargılardan kurtulmasının en etkin yolu erken yaşta başlayan ve psikoseksüel gelişim boyunca devam eden cinsel eğitimdir. İyi bir eğitimin planlanabilmesi için cinsel yanlış inançların nedenlerinin ortaya konması gerekmektedir. Çok yönlü, geniş kapsamlı yeni araştırmalar ile bu konunun aşılması mümkün olabilir.

Anahtar Kelimeler: cinsellik, cinsel mitler, Eysenck kişilik anketi-gözden geçirilmiş̧ kısaltılmış form, cinsel benlik şeması ölçeği

Received date / Geliş tarihi: 29.04.2019, Accepted date / Kabul tarihi:08.07.2019

${ }^{1}$ Ondokuz Mayıs Üniversitesi Tıp Fakültesi Tıp Eğitimi AD., Samsun-TÜRKIYE.

2 Ondokuz Mayıs Üniversitesi Tıp Fakültesi Aile Hekimliği AD., Samsun-TÜRKIYYE.

3 Simurg Akademi, Samsun-TÜRKIYE.

*Address for Correspondence / Yazışma Adresi: Servet Aker, Ondokuz Mayıs Üniversitesi Tıp Fakültesi Tıp Eğitimi AD., Samsun-TÜRKIYE.

E-mail: servetaker@gmail.com

Aker S, Şahin MK, Oğuz G.Sexual Myth Beliefs and Associated Factors in University Students. TJFMPC, 2019;13 (4): $472-480$.

DOI: $10.21763 / \mathrm{tjfmpc} .653462$ 


\section{INTRODUCTION}

Sexuality is a highly complex concept known to involve biological, psychological, social, cultural, traditional, moral, religious, anthropological, political and economic elements. Although sexuality is not essential for the survival of the individual, it underpins several factors responsible for quality of life. ${ }^{1}$

Sexuality is a basic instinct. Every individual has thoughts about sexuality and sexual behavior during his/her childhood, adolescence and adulthood. ${ }^{2}$ Individuals' opinions concerning sexuality can be affected by the culture, religion, and value judgments the community. ${ }^{3}$ Societies transfer patterns of thoughts and ideas as well as judgments maturing over time to next generations. Children learn what is considered appropriate or inappropriate in terms of masculinity or femininity as they grow to maturity in a particular culture. However, a significant part of what they learn and internalize is dysfunctional.

Turkish education system lacks widespread sex education of school age children. ${ }^{4}$ In the absence of formal sources of information on the subject (in the form of school, teachers, specialists, textbook materials etc.) deficiency of accurate understanding is inevitable. ${ }^{4}$ One study in Turkey reported that, regarding sexual information, individuals rely heavily on friends, relatives, newspapers and magazines and pornographic materials. ${ }^{4}$ Much of the information obtained from such an informal sources will inevitably be inaccurate or overstated. This in turn gives rise to a range of sexual prejudices. Sexual myths, which may be defined as inaccurate and overstated beliefs largely devoid of any supporting evidence and passed on by word of mouth, is one of the most common prejudices. These are capable of totally affect one's sexual behavior and attitudes. ${ }^{2,5}$

Together with the traditional approach to sexuality in society, ignorance of the subject can result in a range of sexual problems. ${ }^{6,7}$ Impairment of sexual health first compromise psychological health in both men and women, followed by impairment of family and social health. Sexual incompatibility between husband and wife is a particularly common reason for divorce in Turkey. ${ }^{8}$

Several factors are involved in the development of sexual myths, such as culture, religion and ethnicity. ${ }^{9}$ Sexual myths are not a problem only endemic for Turkey. Similar exaggerated and erroneous sexual beliefs have also been reported in other countries. ${ }^{10}$ One study of Turkish and Polish university students reported similar levels of belief in sexual myths in the two countries. However, the myths upheld differ between Turkish and Polish students. ${ }^{11}$

Little information is available concerning the origins of sexual myths. Studies about the relationship between sexual myths and personality characteristics, sexual self-schemas and self-esteem of the individual are insufficient. Determination of the factors involved in the development of sexual myths will represent the basis of measures aimed at eradicating them.

Although the concept of personality has been investigated in various areas, such as psychology, anthropology and sociology, no specific definition has yet emerged. However, most psychologists have emphasized that personality refers to human individuality or individual differences. The dictionary defines it as all spiritual and cognitive characteristics that separate one individual from others. ${ }^{12}$

Self-schemas have been described as "cognitive generalizations about the self, derived from past experiences that organize and guide the processing of self-related information". ${ }^{13}$ Everything that an individual can know or conceptualize about himself constitutes a basis for the construction of selfschemas. These help the individual to interpret and organize incoming information, on the basis of the particular schemas. In this way, information concerning the self has been shown to be processed more quickly than other information. ${ }^{13}$ Different self-schemas apply to different behavioral domains. ${ }^{14}$ Sexual selfschemas have been defined as cognitive generalizations concerning the individual's own sexual nature. Early childhood and adolescence is important in the development of sexual self-schemas. Several variables can affect the formation of these schemas, such as sexual information obtained, attachment, hormonal development, attitudes toward sexuality and even self-esteem. ${ }^{15}$

Self-esteem is defined in terms of a stable sense of personal worth or worthiness by Rosenberg. ${ }^{16}$ Self-esteem is also a process of self-description and is a positive or negative orientation toward oneself, an overall evaluation of one's worth or value. Yörükoğlu suggests that being confident in self worth, 
able to display knowledge and skills, achieve success and acceptance, and having loving relationships with others, as well as accepting and being content with one's physical traits, are essential factors in the formation and development of self-esteem. ${ }^{17}$ An individual regards himself as positive and worthy while being aware of his faults when his self-esteem is high. When self-esteem is low, one regards himself as deficient in terms of basic individual and social capabilities.

The aim of the study was to examine factors that may be related to belief in sexual myths in university students.

\section{MATERIALS AND METHODS}

\section{Participants}

This study was performed between 01 and 31 May 2016, among students from a private university with approximately 1300 students in four faculties in Samsun, Turkey. We attempted to contact all departments and students at the university. Five hundred ninetynine university students agreeing to participate in the study.

\section{Procedure}

The survey consisted of the Sexual Myths Scale (SMS), Eysenck Personality Questionnaire-Revised/Abbreviated Form, Rosenberg Self Esteem Scale (RSES) and The Sexual Self-Schema Scale (SSS), together with a sociodemographic data form consisting of 15 questions prepared by the authors. After designing the survey, it was administered to 10 students before the study to identify any problems. The survey can be completed in approximately $20 \mathrm{~min}$. The authors entered classrooms together with instructors before the classes began, provided information about the study and themselves. The questionnaires were applied in the class to all students who gave verbal consent to participate.

Students' economic status was evaluated by using the Family Affluence Scale (FAS) in light of data obtained from the sociodemographic data form. The FAS score was calculated separately for each student on the basis of the number of cars in the family, whether the individual had his/her own room, the number of vacations taken in the previous 12 months and the number of computers in the home. ${ }^{18,19}$ Students' opinions concerning religion and political beliefs were evaluated using the questions "How religious do you feel?", "Where do you regard yourself on the political spectrum?", scored on a 9-point Likert-type scale. (1: I Am Not At All Religious 9: I Am Very Religious - 1: Left, 9: Right)

Students in the study came from 66 different provinces of Turkey $(81.5 \%$ of all provinces in the country). The regional classification in the Turkish Demographic Data and Health Survey was used in regional geographical classification. ${ }^{20}$ Provinces were divided into five regions based on socioeconomic and cultural status.

\section{Measures}

Sexual Myths Scale (SMS): Developed by Gölbaşı et al. The scale has been confirmed as valid and reliable for university students. ${ }^{21}$ The SMS is a 5-point Likert-type scale, consisting of 28 items in eight sections (sexual orientation, gender, age and sexuality, sexual behavior, masturbation, sexual violence, sexual intercourse, and sexual satisfaction). It has no cut-off point. A high score indicates that sexual myths are more prevalent.

Eysenck Personality QuestionnaireRevised/Abbreviated Form (EPQR-A): Francis et al. developed the EPQR by reviewing the Eysenck Personality Questionnaire and the abbreviated form. ${ }^{22}$ Karanc1 et al. studied the reliability and validity of the Turkish version of the scale. The scale consists of 24 items and evaluates personality under three main factors (neuroticism, extraversion, and psychoticism). ${ }^{23}$ Eysenck's theory of personality first contained only two domains: neuroticism-stability and extraversionintroversion Psychoticism added afterwards. ${ }^{24}$ Extroversion dimension represents sociality and impulsivity and, individuals in this dimension are energetic, enjoy social interactions, and prefer social situations to loneliness. Neuroticism dimension indicates emotional instability and reactiveness, and that individuals who have high scores in this dimension tend to be anxious, depressive, overly emotional, shy, and have low selfesteem. The psychoticism dimension highlights more bizarre personality characteristics, such as being distant, cold, insensitive, absurd, and unable to empathize with others. $^{23}$

Rosenberg Self Esteem Scale (RSES): Developed by Rosenberg in 1965 in order to measure self-esteem in the general sense. ${ }^{16}$ Çuhadaroğlu showed that the Turkish- 
language adaptation of the scale is a valid and reliable. $^{25}$ This 4-point Likert-type scale consists of 10 items.

The Sexual Self-Schema Scale (SSS): Developed by Hill, the scale was adapted into Turkish by Koçak and showed to be valid and reliable in measuring sexual self-schemas in adult males and females. ${ }^{15,26}$ The scale contains various (33) propositions that people often employ to define themselves in sexual terms. Participants are asked to state the extent to which these titles describe themselves. Each title is evaluated on a 7-point scale from "Does not describe me at all" to "Describes me very well." The Turkish-language version evaluates individuals' sexual self-schemas on a single schema dimension on a range from subjects with positive self-schemas (scoring high) to those with negative self-schemas (scoring low).

\section{Statistical analysis}

The data analyzed with Statistical Package for the Social Sciences (SPSS) software (Version 13.0; SPSS, Inc., Chicago, IL, USA). Data are expressed as mean \pm standard error and number (percentage).

Variable distributions were examined for normality using the Kolmogorov-Smirnov test. The $t$ test and analysis of variance were used to compare mean SMS scores in the groups, and the Pearson correlation and the Spearman correlation analysis were employed to evaluate the power of relations between the SMS and other scale scores. Pearson correlation analysis was used for the data showed parametric characteristics, and the Spearman correlation test was used as its non parametric equivalent. Correlation is an effect size and so we can describe the strength of the correlation for the absolute value of $\mathrm{r}$ : $0.00-0.24$ weak, $0.25-0.49$ moderate, $0.50-0.74$ strong, $0.75-1.00$ very strong. The effect of dependent factors on levels of belief in sexual myths was assessed using multiple regression analysis (enter method) and $p<0.05$ was accepted as statistically significant.

\section{Ethics}

The study procedures were designed to be fully compatible with the Declaration of Helsinki. Ethical approval was granted by the Ondokuz Mayıs University Clinical Research Ethical Committee before the study began (2016-142).

\section{RESULTS}

Five hundred ninety-nine university students participated in the study; $63.1 \%$ were female. The mean age of the students was $21.4 \pm 0.1$ years. Table 1 shows various student characteristics. SMS scores of the students were compared (Table 2) and were significantly lower in females $(p=0,000)$. SMS scores did not differ significantly on the basis of marital status, the geographical region they live mostly, the nature of their place of residence or whether they had experienced a romantic relationship ( $\mathrm{p}>0.05)$. 


\begin{tabular}{|c|c|c|c|}
\hline & & No. & Percentage \\
\hline \multirow[t]{2}{*}{ Gender } & Male & 221 & 36.9 \\
\hline & Female & 378 & 63.1 \\
\hline \multirow[t]{2}{*}{ Marital status } & Single & 569 & 95.0 \\
\hline & Married & 30 & 5.0 \\
\hline \multirow{5}{*}{$\begin{array}{l}\text { Regions of } \\
\text { Turkey }\end{array}$} & North & 350 & 58.4 \\
\hline & South & 26 & 4.3 \\
\hline & West & 61 & 10.2 \\
\hline & East & 58 & 9.7 \\
\hline & Central & 104 & 17.4 \\
\hline \multirow{3}{*}{$\begin{array}{l}\text { Families' place of } \\
\text { residence }\end{array}$} & Villages & 57 & 9.5 \\
\hline & Towns & 163 & 27.2 \\
\hline & Cities & 379 & 63.3 \\
\hline \multirow{6}{*}{$\begin{array}{l}\text { Mother's level of } \\
\text { education }\end{array}$} & Illiterate & 31 & 5.2 \\
\hline & Literate & 24 & 4.0 \\
\hline & Primary school graduate & 134 & 22.4 \\
\hline & Middle school graduate & 88 & 14.7 \\
\hline & High-school graduate & 186 & 31.0 \\
\hline & College graduate & 136 & 22.7 \\
\hline \multirow{6}{*}{$\begin{array}{l}\text { Father's level of } \\
\text { education }\end{array}$} & Illiterate & 13 & 2.2 \\
\hline & Literate & 23 & 3.8 \\
\hline & Primary school graduate & 78 & 13.0 \\
\hline & Middle school graduate & 74 & 12.4 \\
\hline & High-school graduate & 221 & 36.9 \\
\hline & College graduate & 190 & 31.7 \\
\hline \multicolumn{2}{|c|}{ In a romantic relationship a } & $214^{\mathrm{a}}$ & $37.6^{\mathrm{a}}$ \\
\hline \multicolumn{2}{|c|}{$\operatorname{Age}^{b}$} & \multicolumn{2}{|c|}{$21.4 \pm 0.1$} \\
\hline
\end{tabular}

${ }^{\text {a }}$ Among the unmarried subjects (569 individuals)

${ }^{\mathrm{b}}$ Mean \pm standard error

Table 2. Correlations between mean Sexual Myths Scale scores and student characteristics

\begin{tabular}{llcc}
\hline & & Sexual Myths Scale & $\mathrm{p}$ \\
\hline Gender & Male & $80.3 \pm 1.4$ & $\mathbf{0 . 0 0 0}^{*}$ \\
& Female & $68.7 \pm 0.9$ & \\
\hline Marital status & Single & $72.6 \pm 0.8$ & $0.198^{*}$ \\
& Married & $78.2 \pm 2.4$ & \\
\hline Regions of Turkey & North & $70.7 \pm 1.0$ & $0.052^{* *}$ \\
& South & $79.8 \pm 3.7$ & \\
& West & $72.8 \pm 2.7$ & \\
& East & $71.6 \pm 2.3$ & \\
\hline Families' place of & Central & $76.1 \pm 1.9$ & $0.309^{* *}$ \\
residence & Villages & $76.5 \pm 2.9$ & \\
& Towns & $73.7 \pm 1.5$ & \\
\hline In a romantic relationship & Cities & $74.2 \pm 1.0$ & \\
& Yes & $71.6 \pm 1.4$ & \\
& No & $73.2 \pm 1.1$ & \\
\hline
\end{tabular}

* Independent sample $\mathrm{t}$ test

** Analysis of variance

The relationship between continuous variables and the SMS scores of the students were evaluated using correlation analysis (Table 3 ). SMS scores showed a negative correlation 
with maternal and paternal levels of education and a positive correlation with the level of religious belief (Table 3). Students' SMS scores significantly increased as their political opinions tended towards the right and as their psychotic personality traits increased. The SSS and SMS scores of the students also showed positive correlation $(\mathrm{r}=-0.4 ; \mathrm{p}=0.035)$ (Table 3$)$.

\begin{tabular}{|c|c|c|c|}
\hline & \multirow[b]{2}{*}{$\begin{array}{c}\text { Mean } \pm \\
\text { standard error }\end{array}$} & \multicolumn{2}{|c|}{ Sexual Myths Scale } \\
\hline & & $\begin{array}{l}\text { Correlation } \\
\text { Coefficient } \\
\end{array}$ & $\mathrm{p}$ \\
\hline Age & $21.4 \pm 0.1$ & $0.1^{\mathrm{a}}$ & 0.067 \\
\hline Mother's level of education & $9.1 \pm 0.2$ & $-0.2^{b}$ & 0.009 \\
\hline Father's level of education & $10.4 \pm 0.2$ & $-0.3^{b}$ & 0.005 \\
\hline Religious belief $^{\mathrm{c}}$ & $5.1 \pm 0.1$ & $0.5^{b}$ & 0.000 \\
\hline Political opinions ${ }^{\mathrm{d}}$ & $4.8 \pm 0.1$ & $0.4^{\mathrm{b}}$ & 0.000 \\
\hline Family Affluence Scale & $4.0 \pm 0.1$ & $0.1^{\mathrm{a}}$ & 0.532 \\
\hline Rosenberg Self-Esteem Scale & $1.7 \pm 0.1$ & $0.1^{\mathrm{a}}$ & 0.274 \\
\hline The Sexual Self-Schema Scale & $124.3 \pm 1.0$ & $-0.1^{\mathrm{a}}$ & 0.035 \\
\hline \multicolumn{4}{|l|}{ Eysenck Personality Questionnaire } \\
\hline Extraversion & $2.8 \pm 0.1$ & $-0.1^{\mathrm{a}}$ & 0.489 \\
\hline Neuroticism & $3.0 \pm 0.1$ & $-0.1^{a}$ & 0.349 \\
\hline Psychoticism & $2.2 \pm 0.1$ & $0.2^{\mathrm{a}}$ & 0.001 \\
\hline
\end{tabular}

a $r$ (Pearson correlation)

${ }^{b} r_{s}$ (Spearman correlation)

c (1: I Am Not At All Religious, 9: I Am Very Religious)

d(1: Left, 9: Right)

The effect of dependent variables on levels of belief in sexual myths was assessed using multiple regression analysis, the results of which are shown in Table 4. The analysis revealed that gender, religious belief, political opinions, SSS scores and the father's level of education played significant roles in predicting SMS scores $(\mathrm{p}<0.05)$ (Table 4).

\begin{tabular}{|c|c|c|c|c|c|}
\hline Variable & B coefficients & $\beta$ coefficients & $\mathbf{t}$ & $\mathbf{p}$ & \%95 CI \\
\hline Gender $^{\text {a }}$ & 8.7 & 0.2 & 9.7 & 0.000 & $41.3 / 62.2$ \\
\hline Religious belief ${ }^{b}$ & 2.7 & 0.2 & 6.2 & 0.000 & $1.8 / 3.5$ \\
\hline Political opinions ${ }^{c}$ & 1.7 & 0.2 & 4.8 & 0.000 & $1.0 / 2.4$ \\
\hline The Sexual Self-Schema Scale & 0.5 & 0.1 & 2.0 & 0.044 & $0.1 / 1.2$ \\
\hline Father's level of education & -1.7 & -0.1 & -1.9 & 0.048 & $-3.3 /-0.1$ \\
\hline Psychoticism (EPQR-A) & 1.2 & 0.1 & 1.8 & 0.061 & $-0.1 / 2.6$ \\
\hline Mother's level of education & 0.1 & 0.1 & 0.2 & 0.808 & $-1.31 / 1.6$ \\
\hline Constant $=51.7 \quad$ Multible $\mathrm{R}=0.5$ & Multible $\mathrm{R}^{2}=0.2$ & \multicolumn{4}{|c|}{ Durbin-Watson $=1.8(\mathrm{p}=0.001)$} \\
\hline
\end{tabular}

\section{DISCUSSION}

Although sexuality is a part of the human nature, it is a psychophysiological phenomenon shaped by the structure, culture, faiths and precepts of the culture, and can greatly vary between individuals. ${ }^{27,28}$

SMS scores in this study were significantly lower in females. The most comprehensive research concerning sexuality in Turkey was the Sexual Health and Reproductive Health Research conducted in 20 different provinces by the Turkish Association for Sexual Education, Treatment and Research (CETAD). This study concluded that women in Turkey were uninformed on sexual matters, while men were misinformed. ${ }^{4}$ Similarly to our research, one previous study observed significantly less belief in sexual myths among women compared to men. ${ }^{29}$ Even though, there are also studies reporting no difference in levels of 
belief in sexual myths between males and females, but that the myths believed do vary depending on gender. ${ }^{30}$ Two different studies involving students have also reported similar conservative sexual beliefs among men and women. ${ }^{31,32}$ Based on these findings, it may be concluded that the deficient and erroneous beliefs upheld in society affect both sexes, but that belief in sexual myths is more significant in men compared to women.

This study found no significant difference in SMS scores based on marital status, geographical region where students had spent their childhood, the nature of their place of residence or whether or not they had experienced romantic relationships. Similarly to our findings, one study reported no difference in levels of belief in sexual myths depending on where participants live mostly, the geographical regions where their families lived or their families' economic status. ${ }^{32}$ In contrast, there are also studies reporting that living in a village before adolescence significantly increases the level of belief in sexual myths compared to living in a provincial city or district center, and that the level of belief in sexual myths decreases as education levels increase. $^{33}$ One study observed no significant variation in the prevalence of belief in sexual myths between subjects with and without sexual partners. ${ }^{34}$ Another study determined a lower level of belief in sexual myths among subjects with at least one previous sexual experience compared to those with none. ${ }^{35}$ Research also shows a high level of sexual belief among individuals with a high level of education, and even among health workers. ${ }^{34,36}$ It may therefore be concluded that although results vary depending on study populations, many demographic characteristics do not affect the formation of sexual myths.

Students' scores on the SMS increased significantly as their political beliefs tended to the right, and their religious faith increased. One study of Muslim students reported that belief in sexual myths was more prevalent among those who performed daily religious rituals compared to those who did not. ${ }^{35}$ However, sexual myths are not unique to Muslims. They are also common among believers in other faiths. ${ }^{11}$ One example of other faiths' attitude toward sexuality is how the early Christian Church regarded sexual pleasure as sinful, prohibited sexual relations, except for procreation, and forbade masturbation. ${ }^{37}$ It may be concluded that belief in sexual myths increases in line with conservatism and religious faith in all cultures.

In this study, the level of belief in sexual myths significantly decreased with the educational levels of students' fathers. One study reported that the mother's level of education does not affect belief in sexual myths. ${ }^{33}$ Our literature scan revealed no other study investigating individuals' beliefs in sexual myths in terms of parental education levels. We think that families' sociocultural levels may have increased as their educational levels increase. Growing up in a family with a high sociocultural level may also be resulted in reduced belief in sexual myths.

This study determined a significant correlation between students' SSS and SMS scores. However, the relationship is weak. Students with positive sexual self-schemas had lower levels of belief in sexual myths. A few studies have investigated sexual self-schemas in healthy populations. One such study reported that young women in a healthy population with positive sexual self-schemas had more positive opinions regarding sexuality compared to those with negative selfschemas. ${ }^{3}$ Andersen and Cyranowski reported that women with positive sexual self-schemas engaged in a broader range of sexual behavior and experienced more favorable emotions during this. ${ }^{38}$ They described such women as being sexually liberal and less affected by social constraints such as self-consciousness or embarrassment. In contrast, women with negative sexual self-schemas are reported to be generally sexually and socially conservative. ${ }^{39}$ In light of these findings, we may conclude that individuals with negative sexual selfschemas have greater belief in sexual myths.

We determined a positive correlation between students' psychotic personality traits and SMS scores. However, the individual's psychotic personality trait level was not a significant factor to predict SMS scores at multiple regression analysis. Insufficient information is available in the literature on this subject. More comprehensive studies are needed in order to reveal this relationship more explicitly.

\section{CONCLUSION}

Although sexuality is a phenomenon that varies from person to person, and is quite variably affected by cultural and religious factors, dysfunctional beliefs and myths are universal, and are found in many cultures and involve similar themes. Moreover, better 
educated individuals are not immune to these false and exaggerated beliefs. Messages with prejudicial content are ubiquitous, in the family, school, books and novels, poems, films, song lyrics, and in the visual and written media. We all grow up in receipt of these messages, from the adults around us, our parents, other family members, neighbors, teachers and doctors. In other words, none of us is without prejudice. The most effective means to preclude these societal prejudices that can negatively affect individual's sexual life is sex education beginning at an early age and continuing throughout the child's psychosexual development.

\section{REFERENCES}

1. Gülsün M, Ak M, Bozkurt A. Marriage and sexuality from a psychiatric point of view. Curr Approaches Psychiatr 2009;1(1):68-79.

2. Zilbergeld B. The New Male Sexuality. (Revised Edition). NewYork: Batam Books; 1999.p.37-87.

3. Khazaeia M, Rostamib R, Zaryabic A. The Relationship between sexual dysfunctions and marital satisfaction in Iranian married students Procedia. Social and Behavioral Sciences 2011;30:783-85.

4. CETAD. Sexual Education, Treatment and Research Association. Sexual and reproductive health study; 2006. (cited 01 April 2019). Available from: http://www.cetad.org.tr/CetadData/Books/10/2 692011154421-

Arastirma sonuclari Dosyasi_1.pdf

5. Baker C, De Silva P. The relationship between male sexual dysfunction and belief in Zilbergeld's myths: An empirical investigation. Sex Marital Ther 1988;3:229-38.

6. Borg C, de Jong PJ, Schultz W. Vaginismus and dyspareunia: Relationship with general and sex-related moral standards. The Journal of Sexual Medicine 2008;8(1):223-31.

7.Nobre PJ, Pinto-GouveiaJ.

Dysfunctional sexual beliefs as vulnerability factors to sexual dysfunction. Journal of Sex Research 2006;43(1):68-75.

8. Family and Social Policies Ministry, Ankara. Divorce Why Research; 2009 (cited 01 October 2017) Available from: http://ailetoplum.aile.gov.tr/data/54293ea2369 dc32358ee2b25

kutuphane 56 bosanma nedenleri arastirmas i.pdf

9. Leiblum S, Wiegel M, Brickle F. Sexual attitudes of US and Canadian medical students: The role of ethnicity, gender, religion and acculturation. Sex Relationship Ther 2003;18:473-91.
10. Dhall A. Adolescence: Myths and misconteptions. Health Millions 1995;21:2630.

11. Apay ES, Nagorska M, Akpınar RB, Çelik AS, Binkowska-Bury M. Student comparison of sexual myths: Two-country case. Sex Disabil 2013;31:249-62.

12. Haslam N. Introduction to personality and intelligence. London: Sage Publications; 2007.p.3-12.

13. Markus H. Self-schemata and processing information about the self. Journal of Personality and Social Psychology 1977;42:63-78

14. Bruch MA, Kaflowitz NG, Berger P. Selfschema for assertiveness: Extending the validity of the self-schema construct. Journal of Research in Personality 1988;22(4):424-44.

15. Koçak G, Fışılıoğlu H. A validity and reliability study of the sexual seif-schema scale among undergraduate students. Klinik Psikiyatri Dergisi 2010;13(4):159-69.

16. Rosenberg M. Society and the adolescent self-image. Princeton, New Jersey: Princeton University Press; 1965.p.16-36.

17. Yörükoğlu A. Youth Age. 10th Edition. Ankara: Türkiye İş Bankası Yayınları; 1998.p.101-24.

18. Ergin A, Uzun SU, Bozkurt Aİ. Internet addiction prevalence and contributing factors in the medical faculty students. Pamukkale Tip Dergisi 2013;6(3):134-42. (Turkish).

19. Currie CE, Elton RA, Todd J, Platt S. Indicators of socioeconomic status for adolescents: The WHO health behaviour in school-aged children survey. Health Educ Res 1997;12(3):385-97.

20. Hacettepe University Institute of Population Studies, Republic of Turkey Ministry of Development TÜBİTAK Turkey Demographic and Health Surveys 2013. Ankara; 2014.p.xxi-xxii.

21. Gölbası Z, Evcil F, Eroğlu K, Bircan H. Sexual Myths Scale (SMS): Development, validity and reliability in Turkey. Sex Disabil 2016;34(1):75-87.

22. Francis LJ, Brown LB, Philipchalk R. The development of an abbreviated form of the Revised Eysenck Personality Questionnaire (EPQR-A): Its use among students in England, Canada, the USA and Australia. Pers Individ Dif 1992;13:443-9.

23. Karanc1 N, Dirik G, Yorulmaz O. Reliability and validity studies of Turkish translation of Eysenck Personality Questionnaire Revised abbreviated. Turkish Journal of Psychiatry 2007;18(3):1-8.

24. Lewis CA, Francis LJ, Shevlin M, Forrest S. Confirmatory factor analysis of the French translation of the abbreviated form of the 
revised Eysenck Personality Questionnaire (EPQR A). Europe J Psychol Assess 2002;18:179.

25. Çuhadaroğlu F. Self-esteem in adolescents. (Unpublished Doctoral Dissertation) Hacettepe University, Ankara; 1986. p.20-60.

26. Hill DB. Differences and similarities in men's and women's sexual self schemas. Journal of Sex Research 2007;44(2):135-44.

27. Hendrickx K, Lodewijckx E, Van Royen P, Denekens J. Sexual behaviour of second generation Moroccan immigrants balancing between traditional attitudes and safe sex. Patient Educ Couns 2002;47(2):89-94.

28. Sungur MZ. Cultural factors in sex therapy: The Turkish experience. Sex Marital Ther 1999;14(2):165-71.

29. Kukulu K, Gürsoy E, Ak SG. Turkish university students beliefs in sexual myths. Sex Disabil 2009;27(1):49-59.

30. Kora K, Kayır A. Cinsel roller ve cinsel mitler. Düşünen Adam 1996;9:55-58. (Turkish).

31. Yazicı S, Dolgun G, Zengin N, Bayram GO. The determination of university students' knowledge, attitudes and behaviors on the matter of sexual health. Sex Disabil 2012;30:67-75.

32. Ziya ZA. The relatıonshıp between sexual myths, the level of sexual knowledge and sexual attıtudes among university students. (Unpublished Master's Thesis). Haliç University, İstanbul; 2015.p.28-73.
33. Torun F, Torun SD, Özaydın AN. Erkeklerde cinsel mitlere inanma oranlan ve mitlere inanmay1 etkileyen faktörler. Düşünen Adam 2011;24 (1):24-31. (Turkish).

34. Yaşan A, Gürgen F. The ways to get sexual knowledge and the comparison of the rate of sexual myths in nurses who have sexual partners and who do not have. New Symposium Journal 2004;42(2):72-6.

35. Eşsizoğlu A, Yaşan A, Yıldırım EA. Premarital sexual experience and its relationship with conservative sexual myths in male university studens. New Symposium Journal 2009;47(2):80-90.

36. Aker S, Böke Ö. The effect of education on sexual beliefs of family physicians. International Journal of Sexual Health 2016;28(1):111-6.

37. Tannahill R. Sex in History. Gül S. (Translation). Ankara: Dost Kitabevi Yayınlar1; 2003. p.139-40.

38. Andersen BL, Cyranowski JM. Women's sexual self-schema. Journal of Personality and Social Psychology 1994;67:1079-1100.

39. Koçak G. Sexual self-schemas: An exploration of their impact on frequency of masturbation and sexual activity, sexual satisfaction, and marital adjustment. (Unpublished Master's Thesis) Middle East Technical University, Ankara. 2009. p.20-30. 